\title{
Soil Diversity and Key Functional Characteristics of Yakutsk City: Largest Urbanized Cryogenic World's Ecosystem
}

\author{
Vyacheslav Polyakov ${ }^{1,2}\left(\mathbb{D}\right.$, Timur Nizamutdinov ${ }^{1}\left(\mathbb{D}\right.$, Evgeny Abakumov $1, *(\mathbb{D})$ and Eugeniya Morgun ${ }^{3}$ \\ 1 Department of Applied Ecology, Faculty of Biology, St. Petersburg State University, 16th Liniya V.O., 29, \\ 199178 St. Petersburg, Russia; slavon6985@gmail.com (V.P.); timur_nizam@mail.ru (T.N.) \\ 2 Arctic and Antarctic Research Institute, Beringa St. 38, 199397 St. Petersburg, Russia \\ 3 Arctic Research Center of the Yamal-Nenets Autonomous District, Respublikiv St. 20, \\ 629008 Salekhard, Yamal Autonomous Region, Russia; morgun148@gmail.com \\ * Correspondence: e_abakumov@mail.ru; Tel.: +7-953-172-4997
}

Citation: Polyakov, V.;

Nizamutdinov, T.; Abakumov, E.;

Morgun, E. Soil Diversity and Key

Functional Characteristics of Yakutsk City: Largest Urbanized Cryogenic World's Ecosystem. Energies 2021, 14, 3819. https://doi.org/10.3390/ en14133819

Academic Editor: Attilio Converti

Received: 9 June 2021

Accepted: 22 June 2021

Published: 25 June 2021

Publisher's Note: MDPI stays neutral with regard to jurisdictional claims in published maps and institutional affiliations.

\begin{abstract}
Urban soils are the most vulnerable component of the current terrestrial ecosystem. Due to the anthropogenic influence, various pollutants can accumulate in the soils and have a negative effect on the health of citizens. As a result of the degradation of permafrost landscapes, the disappearance of a number of natural ecosystems, as well as urban areas, is possible. In the course of the development of thermokarst processes, problems arise in the urban environment with the destruction of urban buildings and a decrease in agricultural areas. The ecosystem of Yakutsk city is located in the valley of the Lena River and represents the largest urbanized terrestrial biotope, located in the permafrost-affected bioclimatic and geogenic conditions. This work represents relevant datasets on the physico-chemical, toxicological and agrochemical state of soil cover components in various functional zones of the city. An 3excess of the maximum threshold levels for $\mathrm{Zn}$ was noted in the area of active mining within the city borders. From the data obtained of pollution state, the most polluted zone of Yakutsk city is the quarry complex located in relative proximity to the city. In other studied areas of the city, there is no excess of permissible threshold levels for trace elements. According to agrochemical analysis, in Yakutsk city, there is a relatively low content of available agrochemical elements in comparison with other cities located in the permafrost-affected zone.
\end{abstract}

Keywords: trace elements; agrochemical properties; pollution status; permafrost soil; Podzols

\section{Introduction}

The role of soil in an urbanized ecosystem is significant and varied [1,2]. Soil is the main component of the urban ecosystem, in which the air, water and bioinert components of the environment interact [3,4]. Implementing important environment-forming functions, the soil changes the chemical composition of atmospheric precipitation and groundwater, it is a universal sorbent, a supplier and regulator of the content of carbon dioxide, oxygen, nitrogen in the air [5]. Due to its specific properties, the soil largely determines the conditions of human life in the city, performing sanitary and recreational functions $[6,7]$. The sanitary and hygienic functions of the soil are very important, since it is a good antiseptic, self-cleaning from pathogenic microorganisms, decomposing organic residues and metabolic products of living organisms [8,9].

Current soil formation in cities takes place on the cultural soil layer, which is formed due to urbanization of cities and on soils unchanged by soil formation or human influence [1,2]. River floodplains are one of the young and dynamic areas on the Earth's surface [10]. Floodplain soils are found in the newest and recently formed regions (coastal shoals and overgrown ponds) and have a relatively large age range [10]. In permafrostaffected regions, several processes, such as cryogenesis associated with climatic features and the presence of permafrost, and floodplain material transfer (annual flooding), influence soil formation [11]. The flooded areas are landscapes with expressed geochemical 
activity [12]. This explains the high intensity of the soil-forming process in floodplain landscapes [13]. Biological activity and dynamics of chemical and biogeochemical processes determine the fertility of floodplain soils [10].

Most of the coasts of the circumpolar basin in Asia are formed in the permafrostaffected regions [14]. Large northern rivers (Ob, Yenisei, Khatanga, Anabar, Lena, Yana, Kolyma) have a great impact on the Arctic Ocean [7]. This is because rivers are one of the main suppliers of organic and inorganic carbon, trace elements and polyromantic hydrocarbons $[10,15,16]$. Thus, a huge amount of saturated organic material and pollutants enter the Arctic Basin, which is then transformed by marine organisms and participates in the global biogeochemical cycle $[17,18]$.

Nowadays, close attention is riveted to the circumpolar belt due to the intensive rate of landscape transformation in the context of the predicted climatic crisis $[19,20]$. Intense degradation of permafrost and the release of nutrients from the frozen state can lead to an increase in greenhouse gas emissions into the atmosphere, as well as the disappearance of a part of the landscapes that will be subject to active atmospheric influence $[18,21]$. The permafrost zone includes up to 70\% of the area of Russia [7]. The largest permafrost area is located within Siberia and the Far East of Russia-46\%. A characteristic feature of permafrost-affected soils is their temperature regime, in particular, high temperature drops depending on seasonal temperature fluctuations [22,23]. In the circumpolar region, the topsoil temperature can drop to $-30{ }^{\circ} \mathrm{C}$ in winter and not exceed $10{ }^{\circ} \mathrm{C}$ in the summer months. These thermal conditions decrease biological activity, the rate of chemical processes and weathering $[24,25]$. The annual temperature gradient (from unfrozen to freezing conditions) provides a mechanism for the movement of water in the soil, the formation of ground ice and the occurrence of cryogenic processes. Although soil temperature is directly related to air temperature, factors such as vegetation cover, soil moisture, particle-size distribution, snow cover thickness and permafrost table indirectly affect soil formation processes [26].

As a result of the influence of cryogenesis and permafrost on vegetation, development of vascular plants is inhibited, conditions are created for the development of marsh vegetation, shrubs and tundra [14]. On the other hand, condensation of water vapor in permafrost-affected soils is a significant source of water supply for plants [27]. The development of shrubs in vegetation cover contributes to the accumulation of snow, reduces cooling, freezing and cracking, and the development of mosses causes a decrease in heating, thawing and weakens the physical properties of soils [11,27].

The problem of the rational use of cryogenic soils has become especially important in context connection with the intensive development of the Far North, Siberia and the Far East of Russia [28]. In permafrost-affected soils, it is necessary to develop new methods of construction and agriculture use [28]. As a result of the development of the territory, degradation and aggradation of permafrost are possible, causing changes in the position of permafrost table in the soil profile and changes in the duration and seasonal freezingthawing depth [8]. In a course of construction and agriculture in permafrost-affected soils, the following tasks should be carried out: comprehensive land reclamation, increasing bioproductivity, predicting changes in the soil cover, as well as land protection [29]. The leading direction in land protection of permafrost-affected regions is the forecasting of changes in the soil cover, and it is carried out for specific production benefits. Longterm processes of land transformation can lead to flood negative phenomena in soils exposed to the influence of permafrost [30]. The most characteristic changes are subsidence phenomena, which lead to waterlogging and the formation of a network of small lakes, or, with good drainage, to the formation of a residual polygonal relief due to the thawing of ice veins in the soil [31,32]. An important direction in the field of land appraisal located in permafrost-affected soils is the appraisal of land for their further use for various needs [8].

In terms of the main chemical parameters, the urban soils differ significantly from their natural analogs [1]. The acidity of urban soils varies widely, but at the same time, soils 
with a neutral or slightly alkaline environment prevail [1,33]. This is due to the entrance of calcium and sodium chlorides into the soil through surface runoff and drainage water.

Nowadays, the territory adjacent to the city of Yakutsk and Lena River has been studied quite widely, in term of the active development of soil cryogenesis in this region $[23,25,34-36]$, while there are a few works aimed at studying the quality of soils in the city $[36,37]$. The pathogenic microflora of soils [38], the content of trace elements were studied [36,37], the research data were of a point nature and cannot characterize the state of the soils of the city as a whole, there are no works related to the calculation of risks for the city's population.

The soils that form in the urban ecosystem play the role of the basic component $[3,7,39]$. There takes a place a biogeochemical transformation of the cultural layer and the transformation of surface waters into ground waters, which are a nutrient substrate for plants. Urban soils perform many ecological functions, the main ones of which are: suitability for the growth of vegetation cover, the ability to absorb pollutants and keep them from the groundwater, as well as the influence of dust on the atmospheric air [16,39]. Thus, the aim of the work is a comprehensive characterization of the soils of various functional zones of the city of Yakutsk and the adjacent territory. To achieve this aim, the following objectives have been set:

- $\quad$ to determine the basic physical and chemical characteristics of the soils of Yakutsk and the adjacent territory

- to identify the content of the main agrochemical parameters in the soils of Yakutsk and the adjacent territory

- $\quad$ to evaluate the degree of soil pollution in Yakutsk and the adjacent territory with priority toxicants.

\section{Materials and Methods}

\subsection{The Study Area}

The city of Yakutsk is located in the Tuymaada valley on the left bank of the Lena River on modern alluvial deposits with an admixture of pebbles, in its middle course [36]. The area of the city is $122 \mathrm{~km}^{2}$. Yakutsk is the largest Russian city located in the permafrost zone. The city is located on a flat area, on the territory of Yakutsk there are large floodplain lakes: Beloe, Saisary, Teploe, Taloye, Khatyng-Yuryakh, Sergelyakh. The left bank of the river is a scarp up to $100 \mathrm{~m}$ high, covered with pine-larch taiga. One of the peaks is represented by the Chochur-Muran Mountain. The central part of Yakutsk is separated from the Lena River by a wide grassy plain and is flooded during high water. The climate is sharply continental, with little annual precipitation $(237 \mathrm{~mm})$. The average annual temperature of air is $-8.8^{\circ} \mathrm{C}$. The temperature of the warmest month (July) is $38.4{ }^{\circ} \mathrm{C}$. The temperature of the coldest month (January) is $-41.5^{\circ} \mathrm{C}$ [36]. The formation of the relief is greatly influenced by permafrost, the thickness of permafrost ranges from 180 to $400 \mathrm{~m}$. On average, the seasonal thawing depth is 1.1-1.5 m; on sandy soils of southern slopes, it can reach up to $3 \mathrm{~m}$. The city is located on modern alluvial deposits (aIV) [36].

\subsection{Sampling Strategy}

In the city of Yakutsk, soil samples were collected during the 2019 summer field season. The samples were taken in various functional zones of the city: a recreational zone (central park), a quarry complex, the left bank of the Lena River (Chochur-Muran Mountain), modern alluvial territories (city beach) and fallow lands in the south of the city (Figure 1). 

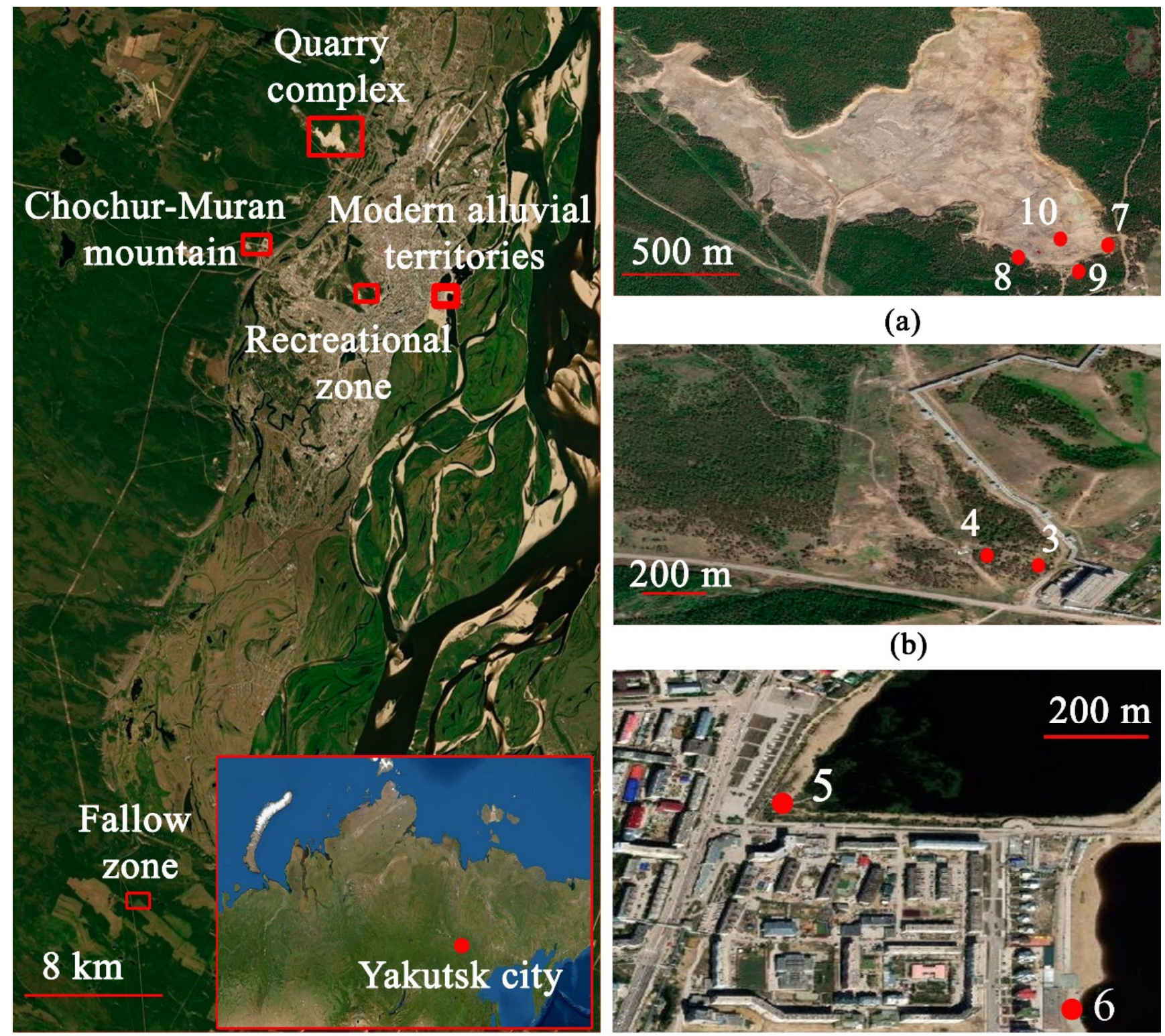

(a)

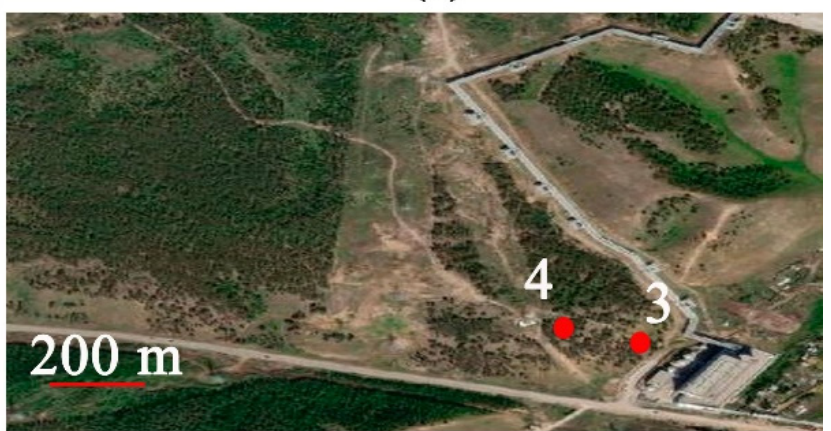

(b)

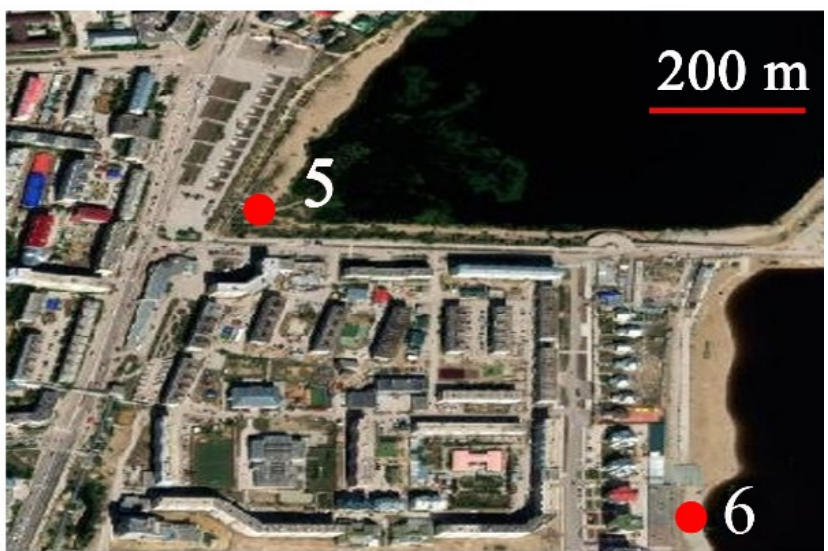

(c)
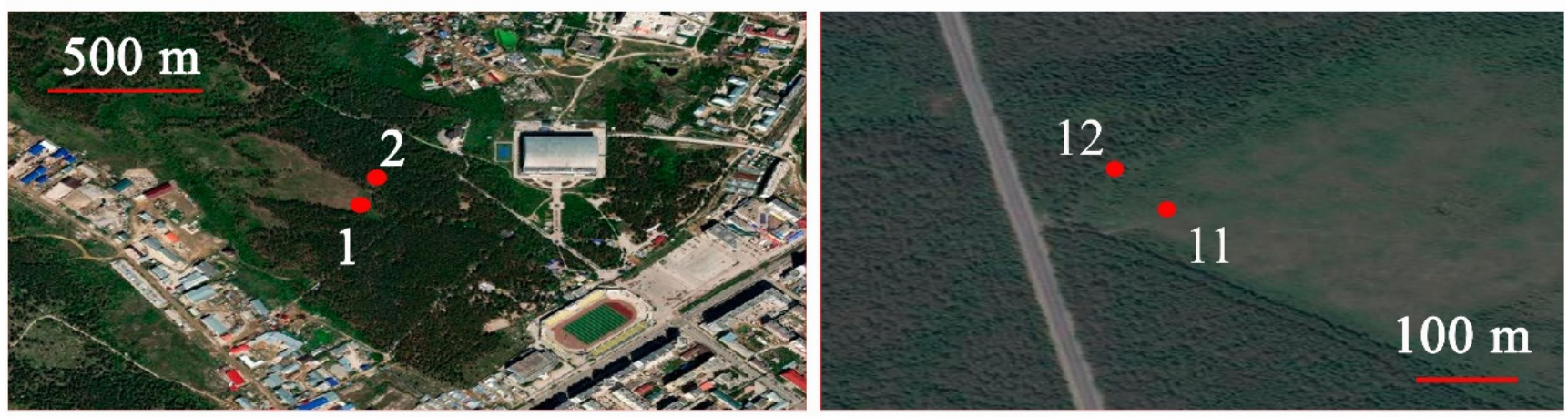

(d)

(e)

Figure 1. The study area. Yakutsk city. (a)—quarry complex, (b)—Chochur-Muran mountain, (c)—modern alluvial territories, (d)—recreational zone, (e)—fallow lands. The soil ID correspond to Table 1. 
Table 1. Description of study soils. Yakutsk city.

\begin{tabular}{|c|c|c|c|c|c|c|}
\hline Soil ID & Depth, cm & Horizon * & Location & Description & Soil Name ${ }^{* *}$ & Coordinates \\
\hline \multicolumn{7}{|c|}{ Recreational zone } \\
\hline 1 & $5-17$ & $\mathrm{Ah}$ & $\begin{array}{l}\text { The central } \\
\text { park of Yakytsk, } \\
\text { non-forest zone }\end{array}$ & $\begin{array}{c}\text { Accumulation } \\
\text { of organic matter } \\
\text { Illuvial accumulation } \\
\text { of clay }\end{array}$ & Podzol & $\begin{array}{l}\mathrm{N} 62^{\circ} 02^{\prime} 14.55^{\prime \prime} \\
\mathrm{E} 129^{\circ} 42^{\prime} 20.14^{\prime \prime}\end{array}$ \\
\hline \multirow[t]{3}{*}{2} & $3-4$ & $\mathrm{Ah}$ & \multirow[t]{3}{*}{$\begin{array}{l}\text { The central park of } \\
\text { Yakytsk, forest zone }\end{array}$} & $\begin{array}{c}\text { Accumulation } \\
\text { of organic matter } \\
\text { Leaching of clay, lighter } \\
\text { than underlying horizon }\end{array}$ & \multirow[t]{3}{*}{ Podzol } & \multirow[t]{3}{*}{$\begin{array}{l}\mathrm{N} 62^{\circ} 02^{\prime} 15.11^{\prime \prime} \\
\mathrm{E} 129^{\circ} 42^{\prime} 23.47^{\prime \prime}\end{array}$} \\
\hline & $4-14$ & $\mathrm{Bt}$ & & $\begin{array}{l}\text { Illuvial accumulation } \\
\text { of clay }\end{array}$ & & \\
\hline & $14-17$ & $\mathrm{Bg}$ & & Accumulation of iron & & \\
\hline \multirow[t]{2}{*}{3} & $0-4$ & $\mathrm{Ah}$ & \multirow[t]{2}{*}{ Chochur-Muran hill } & $\begin{array}{l}\text { Accumulation of } \\
\text { organic matter }\end{array}$ & \multirow[t]{2}{*}{ Podzol } & \multirow{2}{*}{$\begin{array}{l}\mathrm{N} 62^{\circ} 02^{\prime} 50.31^{\prime \prime} \\
\text { E } 129^{\circ} 37^{\prime} 31.59^{\prime \prime}\end{array}$} \\
\hline & $4-30$ & $\mathrm{Bt}$ & & $\begin{array}{l}\text { Illuvial accumulation } \\
\text { of clay }\end{array}$ & & \\
\hline \multirow[t]{2}{*}{4} & $0-23$ & $\mathrm{Ah}$ & \multirow[t]{2}{*}{ Chochur-Muran hill } & $\begin{array}{l}\text { Accumulation of } \\
\text { organic matter }\end{array}$ & \multirow[t]{2}{*}{ Podzol } & \multirow{2}{*}{$\begin{array}{l}\mathrm{N} 62^{\circ} 02^{\prime} 44.70^{\prime \prime} \\
\mathrm{E} 129^{\circ} 37^{\prime} 29.75^{\prime \prime}\end{array}$} \\
\hline & $23-67$ & $\mathrm{Bt}$ & & $\begin{array}{l}\text { Illuvial accumulation } \\
\text { of clay }\end{array}$ & & \\
\hline \multicolumn{7}{|c|}{ Residential zone } \\
\hline \multirow[t]{2}{*}{5} & $0-8$ & Ah & \multirow[t]{2}{*}{$\begin{array}{l}\text { Modern } \\
\text { alluvial areas }\end{array}$} & $\begin{array}{l}\text { Accumulation of } \\
\text { organic matter }\end{array}$ & \multirow[t]{2}{*}{ Fluvisol } & \multirow[t]{2}{*}{$\begin{array}{l}\mathrm{N} 62^{\circ} 02^{\prime} 17.77^{\prime \prime} \\
\mathrm{E} 129^{\circ} 45^{\prime} 26.06^{\prime \prime}\end{array}$} \\
\hline & $8-15$ & $\mathrm{Bt}$ & & $\begin{array}{l}\text { Illuvial accumulation } \\
\text { of clay }\end{array}$ & & \\
\hline \multirow[t]{2}{*}{6} & $0-8$ & $\mathrm{Ah}$ & \multirow{2}{*}{$\begin{array}{l}\text { Modern alluvial } \\
\text { areas, city beach }\end{array}$} & $\begin{array}{c}\text { Accumulation of } \\
\text { organic matter }\end{array}$ & \multirow{2}{*}{ Fluvisol } & \multirow{2}{*}{$\begin{array}{l}\mathrm{N} 62^{\circ} 02^{\prime} 03.18^{\prime \prime} \\
\mathrm{E} 129^{\circ} 45^{\prime} 57.03^{\prime \prime}\end{array}$} \\
\hline & $8-26$ & $\mathrm{Bt}$ & & $\begin{array}{l}\text { Illuvial accumulation } \\
\text { of clay }\end{array}$ & & \\
\hline \multicolumn{7}{|c|}{ Industrial zone } \\
\hline \multirow[t]{2}{*}{7} & $0-7$ & Ah & \multirow[t]{2}{*}{$\begin{array}{l}\text { Southeast side of the } \\
\text { sand quarry }\end{array}$} & $\begin{array}{l}\text { Accumulation of } \\
\text { organic matter }\end{array}$ & \multirow[t]{2}{*}{ Podzol } & \multirow[t]{2}{*}{$\begin{array}{l}\mathrm{N} 62^{\circ} 05^{\prime} 11.21^{\prime \prime} \\
\mathrm{E} 129^{\circ} 41^{\prime} 19.44^{\prime \prime}\end{array}$} \\
\hline & $29-56$ & $\mathrm{Bt}$ & & $\begin{array}{l}\text { Illuvial accumulation } \\
\text { of clay }\end{array}$ & & \\
\hline \multirow[t]{2}{*}{8} & $0-10$ & $\mathrm{Ah}$ & \multirow[t]{2}{*}{$\begin{array}{l}\text { Southwest side of the } \\
\text { sand quarry }\end{array}$} & $\begin{array}{l}\text { Accumulation of } \\
\text { organic matter }\end{array}$ & \multirow[t]{2}{*}{ Podzol } & \multirow[t]{2}{*}{$\begin{array}{l}\text { N } 62^{\circ} 05^{\prime} 10.42^{\prime \prime} \\
\text { E } 129^{\circ} 41^{\prime} 02.32^{\prime \prime}\end{array}$} \\
\hline & $30-73$ & $\mathrm{Bg}$ & & $\begin{array}{l}\text { 1Iluvial accumuiation } \\
\text { of clay }\end{array}$ & & \\
\hline 9 & $10-24$ & $\mathrm{Bt}_{1}$ & $\begin{array}{l}\text { South side of the } \\
\text { sand quarry }\end{array}$ & $\begin{array}{l}\text { Illuvial accumulation } \\
\text { of clay }\end{array}$ & Podzol & $\begin{array}{l}\mathrm{N} 62^{\circ} 05^{\prime} 08.56^{\prime \prime} \\
\mathrm{E} 129^{\circ} 41^{\prime} 08.52^{\prime \prime}\end{array}$ \\
\hline & $50-74$ & $\mathrm{Bt}_{2}$ & & $\begin{array}{l}\text { clinvial accumulation of } \\
\text { cland iron }\end{array}$ & & \\
\hline 10 & $0-10$ & $\mathrm{C}$ & The bottom & $\begin{array}{l}\text { Parent rock little affected } \\
\text { by pedogenetic processes }\end{array}$ & Leptosol & $\mathrm{N} 62^{\circ} 05^{\prime} 10.82^{\prime \prime}$ \\
\hline & $10-20$ & $\mathrm{Cg}$ & of rhe quarry & Accumulation of iron & & E $129^{\circ} 41^{\prime} 15.94^{\prime \prime}$ \\
\hline & & & Fallon & zone & & \\
\hline 11 & $0-20$ & $\mathrm{Ah}$ & Abandoned soils & $\begin{array}{c}\text { Accumulation of } \\
\text { organic matter }\end{array}$ & Umbrisol & N 61 $41^{\circ} 27.91^{\prime \prime}$ \\
\hline & $20-50$ & $\mathrm{Bh}$ & & $\begin{array}{l}\text { Accumulation of organic } \\
\text { matter by illuviation }\end{array}$ & & $.26^{\prime \prime}$ \\
\hline 12 & $0-20$ & $\mathrm{Ah}$ & $\begin{array}{l}\text { Adjacent territory to } \\
\text { abandoned soils }\end{array}$ & $\begin{array}{l}\text { Accumulation of } \\
\text { organic matter }\end{array}$ & Umbrisol & $\begin{array}{l}\mathrm{N} 61^{\circ} 49^{\prime} 30.10^{\prime \prime} \\
\mathrm{E} 129^{\circ} 31^{\prime} 37.95^{\prime \prime}\end{array}$ \\
\hline
\end{tabular}


During the work, 12 soil sections were made (Figure 2).

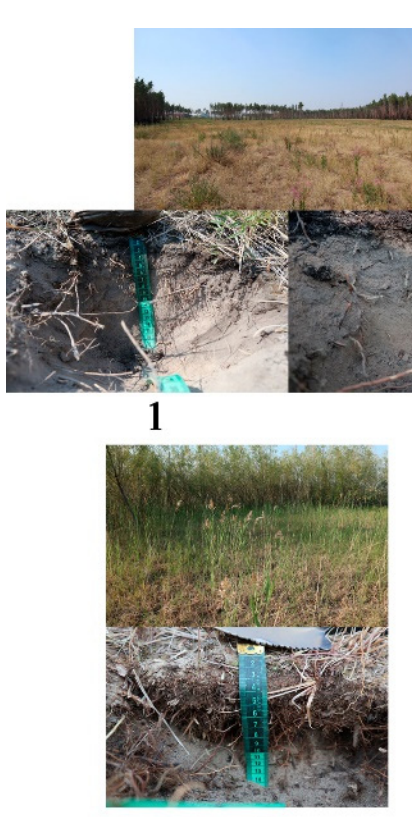

5

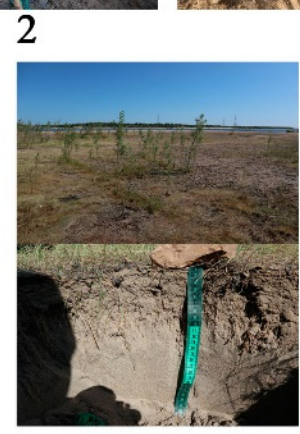

6

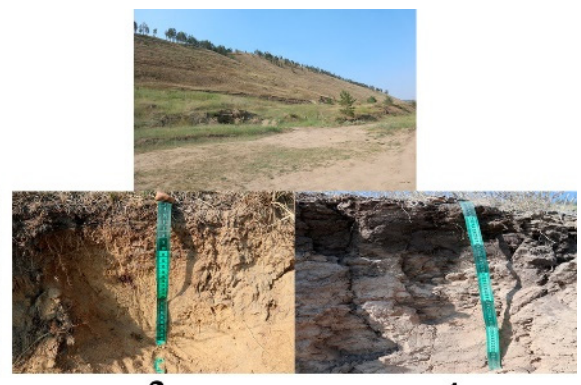

3

4

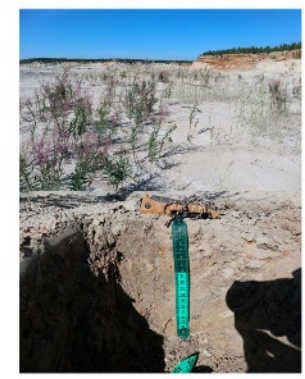

10

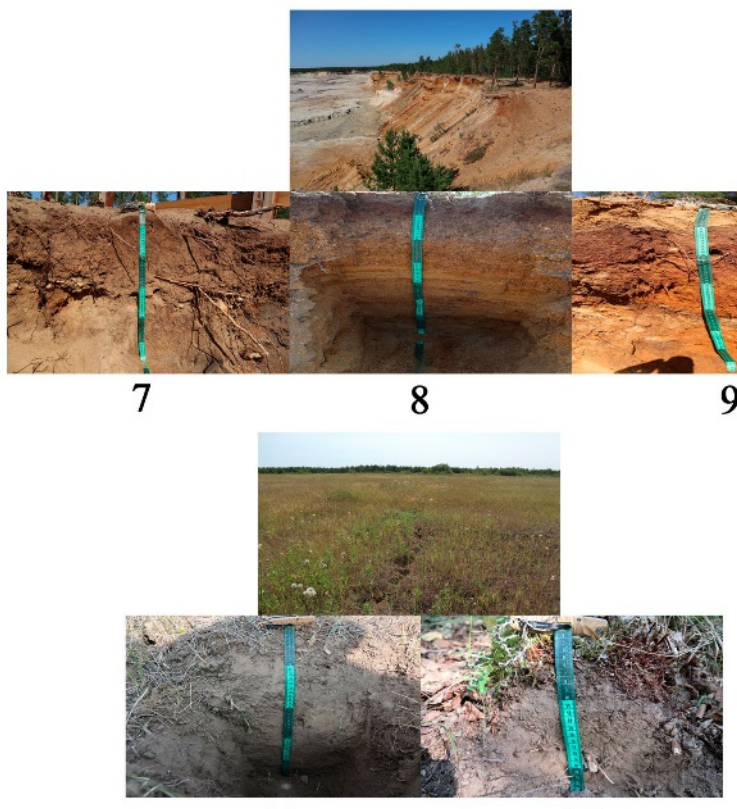

11

12

Figure 2. Soil profiles from the Yakutsk city and the adjacent territory. The soil ID correspond to Table 1.

Depending on the soil formation conditions, the following soil types were identified: Podzols, Umbrisols, Leptosols and Fluvisols [40] (Table 1).

\subsection{Laboratory Analysis}

All samples were dried at the $+25^{\circ} \mathrm{C}$ at the Department of Applied ecology of SaintPetersburg state university and then sieved through 2-mm sieve. The $\mathrm{pH}$ was determined by $\mathrm{pH}$-meter in $\mathrm{H}_{2} \mathrm{O}$ and $\mathrm{CaCl}_{2}$ suspensions with fine-earth: solution ratio 1:2.5 for mineral fine earth and 1:25 for organic substrata. The carbon content (C) was determined by dichromate oxidation-titration method [42]. The particle-size distribution analysis was carried out according to the Kachinsky "wet sedimentation" method, which is the Russian analog of analysis by Bowman [43]. Main agrochemical characteristics such as mobile phosphorus and potassium were determined using the standard procedures according to 
GOST [44], which is based on extracting mobile phosphorus $\left(\mathrm{P}_{2} \mathrm{O}_{5}\right)$ and potassium $\left(\mathrm{K}_{2} \mathrm{O}\right)$ compounds from the soil with a hydrochloric acid solution and quantitatively determining the phosphorus and potassium content. Available forms of nitrogen $\left(\mathrm{NO}_{3}\right)$ were determined according to ISO 14256-1 [45], which first extracts exchangeable ammonium $\left(\mathrm{N}^{-\mathrm{NH}_{4}}\right)$ from the soil with a potassium chloride solution and then photometrically measures the colored solution. Trace elements content was determined by flame and electrothermal atomic absorption spectrometric method according to the standard ISO 11047-1998 at Atomic absorption spectrophotometer Kvant 2M (Moscow, Russia). Extraction of trace elements was carried out by the acid-soluble method in a solution of $5 \mathrm{M} \mathrm{HNO}_{3}$ [46].

\subsection{Data Processing}

To qualitatively assessing of soil contamination with trace metals, we used a number of complex and individual indices. Single pollution index $(P I)$ is used to calculate some other soil pollution indices, such as Pollution load index (PLI) and potential ecological risk (RI) [47]. The generic formula is as follows:

$$
P I=\frac{C n}{G B}
$$

where, $C n$-the content of heavy metal in soil and $G B$-values of the geochemical background.

Pollution load index (PLI), it is calculated as a geometric average of $P I$ values [47]. The generic formula:

$$
P L I=\sqrt[n]{P I_{1} \times P I_{2} \times P I_{3} \times \ldots P I_{n}}
$$

where: $n$-the number of analyzed metals and $P I$-calculated values for the single pollution index.

Potential ecological risk $(R I)$ is used to estimate the degree of ecological risk associated with detrimental effects of trace metals [48]. The generic formula as follows:

$$
R I=\sum_{i=1}^{n} E_{r}^{i}
$$

where: $n$-the number of heavy metals and $E r$-single index of the ecological risk factor calculated based on the formula:

$$
E_{r}^{i}=T_{r}^{i} \times P I
$$

where: $\mathrm{Tr}$-the toxicity response coefficient of an individual metal (Ni, Pb, Cu-5; $\mathrm{Zn}-2)$ [17] and PI-calculated values for the single pollution index.

All of the applied indices have their own evaluation scales, which are shown in Table 2.

Table 2. Evaluation scales of used indexes $[47,48]$.

\begin{tabular}{cccccc}
\hline & PI & & PLI & RI \\
\hline Value & Soil pollution & Value & Pollution status & Value & Potential Ecological \\
PI $<1$ & Absent & $<1$ & Denote perfection & $<90$ & Risk \\
$1<$ PI $<2$ & Low & 1 & Only baseline levels of pollution & $90-180$ & Low \\
$2<$ PI $<3$ & Moderate & $>1$ & Deterioration of soil quality & $180-360$ & Moderate \\
$3<$ PI $<5$ & Strong & & & $360-720$ & Strong \\
PI $>5$ & Very strong & & & $\geq 720$ & Very strong \\
\hline
\end{tabular}

The Statsoft Statistica 12.0 and GraphPad Prizm 9.0.0 software was used for statistical processing and data visualization. 


\section{Results and Discussion}

\subsection{The Physic-Chemical Characteristic of Study Soils}

The soils of the city of Yakutsk are characterized by an acidic, neutral and alkaline $\mathrm{pH}$ reaction (Table 3). The relatively high range is due to the high heterogeneity of the territory. The highest $\mathrm{pH}$ values are in the area of fallow lands, which is apparently associated with alkalization of the territory [33]. During the hot summer period, the cations are pulled up to the soil surface [49]. In this area, the presence of an irrigation system was noted, which existed during the times of the USSR and the functioning of the agricultural complex, after the collapse of the USSR, this territory was abandoned [33]. The presence of an alkaline environment is also confirmed in the data obtained by other researchers in the urban environment $[3,36,39]$. The lowest $\mathrm{pH}$ values are confined to the area of the quarry, this may be due to the acidic reaction of the parent material. On average, the reaction of the soil is characterized by a neutral reaction, which is associated with a weak process of podzol formation in the studied soils and a low amount of atmospheric precipitation. The highest carbon content is characteristic of natural soils on Chochur-Muran Mountain, which is associated with the active accumulation of litter and its transformation during humification in the upper soil horizons. The lowest organic carbon content was determined in the Bt horizon in the soil of Yakutsk Park. On average, the soil accumulates up to $2.4 \%$ of organic carbon. The low humidity of the territory prevents the active processes of humification and the activity of the soil biota [5]. Indicators of organic carbon content outside the city are higher, which is associated with more active processes of accumulation of litter material [50].

Table 3. The physic-chemical characteristic of study soils. The soil ID correspond to Table 1. SOC, \%—soil organic carbon; $\mathrm{SD}$-standard deviation; CV—coefficient variation.

\begin{tabular}{|c|c|c|c|c|c|c|c|c|}
\hline \multirow{2}{*}{ Soil ID } & \multirow{2}{*}{ Depth } & \multirow{2}{*}{ Horizon } & \multicolumn{2}{|c|}{$\mathrm{pH}$} & \multirow{2}{*}{$\mathrm{SOC}, \%$} & \multicolumn{3}{|c|}{ Particle-Size Distribution, \% } \\
\hline & & & $\mathrm{H}_{2} \mathrm{O}$ & $\mathrm{CaCl}_{2}$ & & Clay & Silt & Sand \\
\hline \multicolumn{9}{|c|}{ Recreational zone } \\
\hline \multirow{3}{*}{1} & $0-5$ & $\mathrm{Ah}$ & 7.29 & n.d. & 1.5 & 2 & 26 & 72 \\
\hline & $5-17$ & $\mathrm{Bt}$ & 5.90 & 5.36 & 1.2 & 5 & 14 & 81 \\
\hline & $0-3$ & $\mathrm{Ah}$ & 7.34 & n.d. & 3.3 & 1 & 24 & 75 \\
\hline \multirow{3}{*}{2} & $3-4$ & $\mathrm{E}$ & 7.31 & n.d. & 2.7 & 1 & 24 & 75 \\
\hline & $4-14$ & $\mathrm{Bt}$ & 7.28 & n.d. & 1.8 & 1 & 33 & 66 \\
\hline & $14-17$ & $\mathrm{Bg}$ & 7.04 & n.d. & 1.5 & 6 & 44 & 50 \\
\hline \multirow[b]{2}{*}{3} & $0-4$ & $\mathrm{Ah}$ & 7.42 & n.d. & 2.7 & 14 & 34 & 52 \\
\hline & $4-30$ & $\mathrm{Bt}$ & 7.56 & n.d. & 2.4 & 20 & 20 & 60 \\
\hline \multirow[b]{2}{*}{4} & $0-23$ & $\mathrm{Ah}$ & 7.32 & n.d. & 4.2 & 6 & 47 & 47 \\
\hline & $23-67$ & $\mathrm{Bt}$ & 6.08 & 4.84 & 4.2 & 16 & 38 & 46 \\
\hline \multicolumn{9}{|c|}{ Residential zone } \\
\hline \multirow[b]{2}{*}{5} & $0-8$ & Ah & 7.50 & n.d. & 2.4 & 7 & 14 & 79 \\
\hline & $8-15$ & $\mathrm{Bt}$ & 7.43 & n.d. & 1.2 & 11 & 3 & 86 \\
\hline \multirow[b]{2}{*}{6} & $0-8$ & $\mathrm{Ah}$ & 6.40 & 5.59 & 2.4 & 1 & 10 & 89 \\
\hline & $8-26$ & $\mathrm{Bt}$ & 6.92 & n.d. & 2.4 & 12 & 7 & 81 \\
\hline \multirow[b]{2}{*}{7} & $0-7$ & & & Industrial zone & & & & \\
\hline & $\begin{array}{c}0-7 \\
29-56\end{array}$ & $\begin{array}{l}\mathrm{Ah} \\
\mathrm{Bt}\end{array}$ & $\begin{array}{l}7.03 \\
6.33\end{array}$ & $\begin{array}{l}\text { n.d. } \\
5.31\end{array}$ & $\begin{array}{l}3.6 \\
3.6\end{array}$ & $\begin{array}{c}1 \\
10\end{array}$ & $\begin{array}{c}11 \\
5\end{array}$ & $\begin{array}{l}88 \\
85\end{array}$ \\
\hline \multirow{2}{*}{8} & $0-10$ & $\mathrm{Ah}$ & 6.86 & 6.05 & 3.3 & 5 & 17 & 78 \\
\hline & $30-73$ & $\mathrm{Bg}$ & 5.97 & 5.57 & 2.4 & 10 & 33 & 57 \\
\hline \multirow{2}{*}{9} & $10-24$ & $\mathrm{Bt}_{1}$ & 6.02 & 5.25 & 3.0 & 3 & 30 & 67 \\
\hline & $50-74$ & $\mathrm{Bt}_{2}$ & 6.20 & 5.79 & 1.5 & 11 & 6 & 83 \\
\hline \multirow{2}{*}{10} & $0-10$ & $\mathrm{C}$ & 3.64 & 3.42 & 1.7 & 1 & 60 & 39 \\
\hline & $10-20$ & $\mathrm{Cg}$ & 3.94 & 3.37 & 1.5 & 17 & 27 & 56 \\
\hline \multirow{3}{*}{11} & & & & Fallow zone & & & & \\
\hline & $0-20$ & $\mathrm{Ah}$ & 8.55 & n.d. & 2.7 & 7 & 39 & 54 \\
\hline & $20-50$ & $\mathrm{Bh}$ & 8.53 & n.d. & 1.9 & 8 & 45 & 47 \\
\hline \multirow[t]{6}{*}{12} & $0-20$ & $\mathrm{Ah}$ & 4.67 & 3.88 & 1.3 & 2 & 43 & 55 \\
\hline & Min & & 3.64 & 3.37 & 1.2 & 1 & 3 & 39 \\
\hline & Max & & 8.55 & 6.05 & 4.2 & 17 & 60 & 96 \\
\hline & Mean & & 6.66 & 4.94 & 2.4 & 5 & 26 & 69 \\
\hline & $\mathrm{SD}$ & & 1.21 & 0.95 & 0.9 & 5 & 15 & 17 \\
\hline & $\mathrm{CV}$ & & 18.1 & 19.2 & 37.1 & 106 & 58 & 25 \\
\hline
\end{tabular}


From the analysis of the particle-size distribution, it was noted that soils develop according to the podzolic type of soil formation with accumulation of smaller particles (clay, dust) [50]. In modern reclaimed soils, an increase in the proportion of clay particles in the underlying horizons is observed. In fallow lands (No. 11), an increase in the proportion of clay and dust particles along with humus is observed, since humus is more involved in the structure of smaller particles due to their larger area [49].

\subsection{The Agrochemical Characteristic of Study Soils}

According to the data obtained in the soils (Table 4, Figure 3), there is a relatively low level of nutrients in comparison with the fallow lands in the city of Salekhard [33], which is also located in the permafrost zone and on the alluvial soil with the presence of fallow land. The highest content of $\mathrm{P}_{2} \mathrm{O}_{5}$ is observed in soils at the foot of the Chochur-Muran Mountain, this may be due to the surface transfer of mobile forms of nutrients and their accumulation at the foot of the mountain. This trend can be seen in samples from the bottom of the quarry. In fallow soils, the phosphorus content is relatively high among the studied soils. A significant portion of the available soil phosphorus is present in organic matter. In alkaline soils, the solubility of phosphorus depends on the amount of available calcium in soil. Calcium is a major element in alkaline soils and reacts with $\mathrm{HPO}_{4}{ }^{2-}$ in the form of calcium phosphate $\left(\mathrm{CaP}_{2} \mathrm{O}_{7}\right)$. Calcium phosphate in an alkaline environment has low solubility, thus, less available to plants. Soils removed from agriculture are able to retain their properties for a long time [51].

Table 4. The agrochemical parameters of study soils in Yakutsk city. The soil ID correspond to Table 1. SD-standard deviation; CV-coefficient variation.

\begin{tabular}{|c|c|c|c|c|c|c|}
\hline \multirow{2}{*}{ Soil ID } & \multirow{2}{*}{ Depth, cm } & \multirow{2}{*}{ Horizon } & $\mathrm{P}-\mathrm{P}_{2} \mathrm{O}_{5}$ & $\mathrm{~K}-\mathrm{K}_{2} \mathrm{O}$ & $\mathrm{N}-\mathrm{NH}_{4}$ & $\mathrm{~N}-\mathrm{NO}_{3}$ \\
\hline & & & \multicolumn{4}{|c|}{$\mathrm{mg} \times \mathrm{kg}^{-1}$} \\
\hline \multirow{4}{*}{1} & & & Recreational zone & & & \\
\hline & $0-5$ & $\mathrm{Ah}$ & 46 & 174 & 19.2 & 0.83 \\
\hline & $5-17$ & $\mathrm{Bt}$ & 97 & 83 & 11.5 & 0.35 \\
\hline & $0-3$ & $\mathrm{Ah}$ & 107 & 239 & 28.7 & 0.58 \\
\hline \multirow{3}{*}{2} & $3-4$ & E & 71 & 161 & 25.5 & 0.58 \\
\hline & $4-14$ & $\mathrm{Bt}$ & 53 & 110 & 15.7 & 0.64 \\
\hline & $14-17$ & $\mathrm{Bg}$ & 46 & 92 & 14.7 & 0.45 \\
\hline \multirow[b]{2}{*}{3} & $0-4$ & $\mathrm{Ah}$ & 185 & 276 & 16.6 & 2.82 \\
\hline & $4-30$ & $\mathrm{Bt}$ & 127 & 110 & 7.4 & 0.64 \\
\hline \multirow[b]{2}{*}{4} & $0-23$ & $\mathrm{Ah}$ & 334 & 225 & 15.6 & 0.89 \\
\hline & $23-67$ & $\mathrm{Bt}$ & 410 & 142 & 9.48 & 0.19 \\
\hline \multirow[b]{3}{*}{5} & & & Residential zone & & & \\
\hline & $0-8$ & $\mathrm{Ah}$ & 143 & 285 & 23.9 & 0.11 \\
\hline & $8-15$ & $\mathrm{Bt}$ & 183 & 37 & 6.7 & 0.22 \\
\hline \multirow[b]{2}{*}{6} & $0-8$ & $\mathrm{Ah}$ & 212 & 46 & 9.1 & 0.67 \\
\hline & $8-26$ & $\mathrm{Bt}$ & 191 & 23 & 7.1 & 1.57 \\
\hline \multirow[b]{3}{*}{7} & & & Industrial zone & & & \\
\hline & $0-7$ & $\mathrm{Ah}$ & 13 & 74 & 12.7 & 2.24 \\
\hline & $29-56$ & $\mathrm{Bt}$ & 11 & 48 & 7.2 & 1.15 \\
\hline \multirow{2}{*}{8} & $0-10$ & $\mathrm{Ah}$ & 9 & 96 & 11.3 & 1.54 \\
\hline & $30-73$ & $\mathrm{Bg}$ & 6 & 28 & 7.1 & 0.51 \\
\hline \multirow[b]{2}{*}{9} & $10-24$ & Bt1 & 10 & 60 & 9.7 & 1.06 \\
\hline & $50-74$ & Bt2 & 4 & 28 & 7.7 & 1.15 \\
\hline \multirow{3}{*}{10} & $0-10$ & $\mathrm{C}$ & 399 & 32 & 12.9 & 0.96 \\
\hline & $10-20$ & $\mathrm{Cg}$ & 313 & 83 & 11.3 & 0.11 \\
\hline & & & Fallow zone & & & \\
\hline \multirow{2}{*}{11} & $0-20$ & $\mathrm{Ah}$ & 369 & 372 & 13.3 & 0.89 \\
\hline & $20-50$ & $\mathrm{Bh}$ & 279 & 147 & 7.9 & 1.98 \\
\hline \multirow[t]{7}{*}{12} & $0-20$ & $\mathrm{Ah}$ & 130 & 188 & 20.1 & 0.58 \\
\hline & Abandoned soils of Sale & & 783 & 469 & & \\
\hline & Min & & 4.27 & 23 & 6.7 & 0.11 \\
\hline & Max & & 410 & 372 & 28.7 & 2.82 \\
\hline & Mean & & 150 & 126 & 13.3 & 0.89 \\
\hline & SD & & 133 & 93 & 6.2 & 0.68 \\
\hline & $\mathrm{CV}$ & & 88 & 74 & 46.4 & 76.6 \\
\hline
\end{tabular}




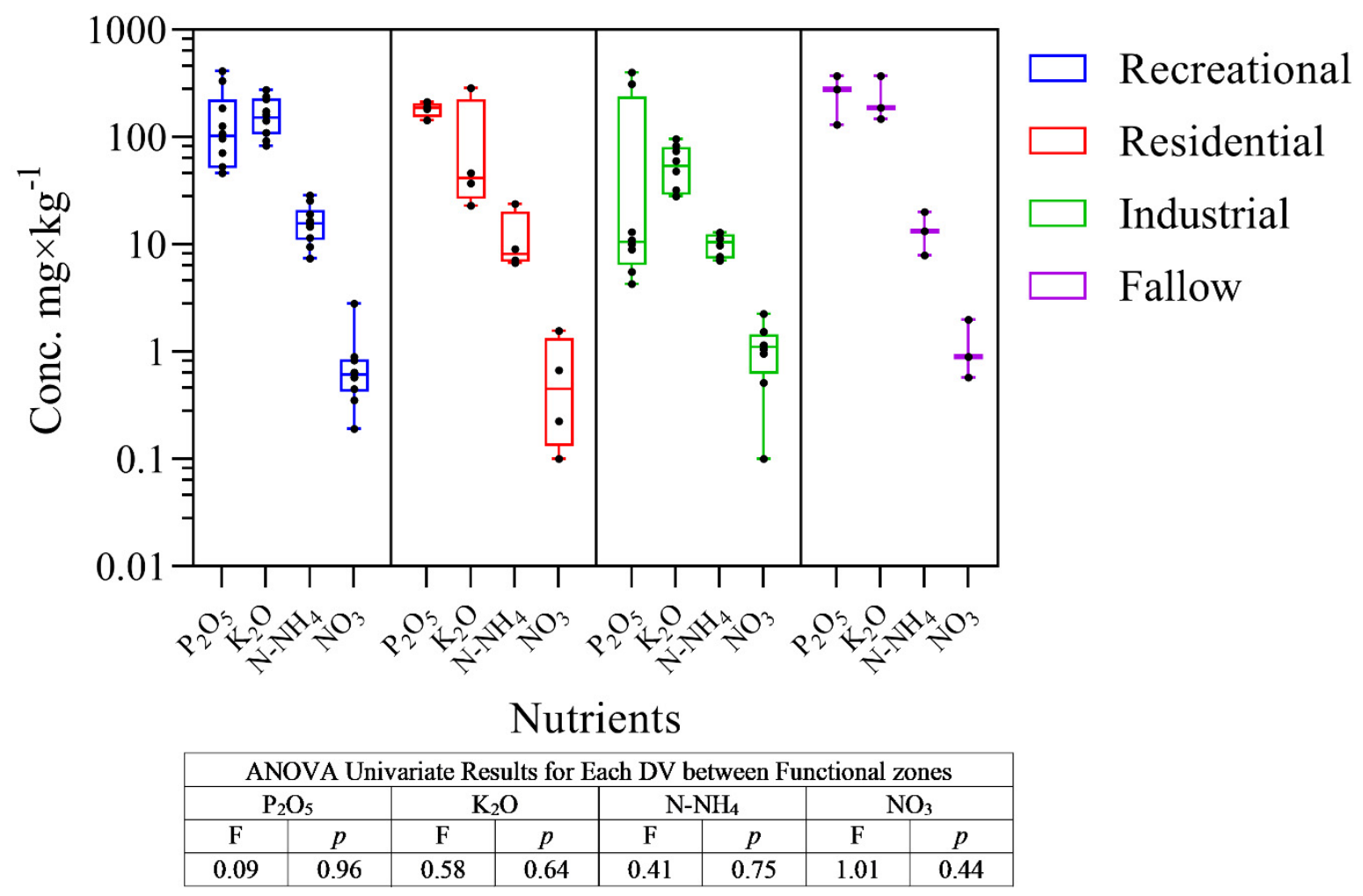

Figure 3. Variation in the content of nutritional elements and the results of statistical data processing.

The $\mathrm{K}-\mathrm{K}_{2} \mathrm{O}$ content in the studied soils is also lower than in the soils of the city of Salekhard [33]. The highest potassium content is observed in the fallow soil. It is connected with agrotechnical measures that were carried out earlier. The physiological functions of potassium in the plant organism are varied. It has a positive effect on the physical state of cytoplasmic colloids, increases their water content, swelling and viscosity, which is of great importance for the normal metabolism in cells, as well as for increasing plant resistance to drought [52].

Nitrogen in soils is found mainly in an organic form inaccessible to plants. Under the influence of biological processes, organic nitrogen partially transforms into mineral forms easily assimilated by plants [53]. The decomposition of nitrogen organic matter in the soil to ammonia (ammonification) is carried out by aerobic and anaerobic microorganisms. Ammonia, which accumulates under anaerobic conditions, is absorbed by soil colloids and can be absorbed by plants [54]. Under aerobic conditions, ammonia, under the influence of specific microorganisms, is converted into nitrites and then oxidized to nitrates (nitrification). A certain amount of mineral nitrogen enters the soil with precipitation. Atmospheric nitrogen is also assimilated by individual microorganisms and by nodule bacteria of leguminous plants. In a neutral environment, the effect of ammonia nitrogen is usually better than nitrate nitrogen. For the synthesis of organic substances, plants use ammonia nitrogen faster than nitrate nitrogen. The advantage of ammonia nutrition in comparison with nitrate nutrition is that ammonia nitrogen is closer to the products of the synthesis of nitrogen-containing substances in plants [51]. The studied soils predominantly accumulate the ammonia form of nitrogen. The highest content is noted in the litter of natural soils in the park zone.

In the floodplains areas of the city, the accumulation of $\mathrm{K}-\mathrm{K}_{2} \mathrm{O}, \mathrm{N}-\mathrm{NH}_{4}$ and $\mathrm{N}-\mathrm{NO}_{3}$ occurs to a lesser extent. Modern hydrostructures are rather slowly involved in soil formation. Low levels of carbon content, nutrients cause low buffering (resistance to external factors) of such soils, so can accumulate more pathogenic organisms and priority toxicants [51]. Therefore, on alluvial soils, before involving them in various types of work, 
it is necessary to carry out reclamation measures [55]. In the course of land reclamation, the structure as well as the buffering capacity of such lands is improved [33].

The results of the analysis of variance ANOVA showed no significant differences in the content of nutrients in soils between the different functional zones. Fisher's F-criterion and $p$-values show the absence of statistically significant differences in the mean values of nutrient concentrations. The $p$-values obtained in the results of statistical analysis considerably exceed the critical value of 0.05 . This indicates the absence of significant statistical differences in the mean values of the content of nutrients between the studied functional zones.

\subsection{The Content of Trace Elements of Study Soils}

In the studied soils, an excess of the maximum permissible concentration for $\mathrm{Zn}$ is stated (Table 5, Figure 4). The most contaminated soils are formed at the bottom of the quarry complex. This is due to the fact that the bottom of the quarry is a place of accumulation of pollutants by rainwater. Among the studied soils, the highest indicators for copper, zinc, nickel and cadmium are observed. High indicators of these substances can also be associated with the activity of mining equipment, at the time of the sampling of the material, transport activity was noted in the quarry complex [7]. Other studied soils are less susceptible to pollution and do not exceed the maximum permissible concentration. The data obtained correspond to the previously obtained results [35,37]. It was noted that the highest lead content is observed in the upper (Ah) horizon in the city's park zone, while it does not exceed the MPC.

Table 5. The content of trace metals it the studied soils.

\begin{tabular}{|c|c|c|c|c|c|c|c|}
\hline \multirow{2}{*}{ Soil ID } & \multirow{2}{*}{ Depth } & \multirow{2}{*}{ Horizon } & $\mathrm{Cu}$ & $\mathrm{Pb}$ & $\mathrm{Zn}$ & $\mathrm{Ni}$ & $\mathrm{Cd}$ \\
\hline & & & \multicolumn{5}{|c|}{$\mathbf{m g} \times \mathbf{k g}^{-1}$} \\
\hline \multicolumn{8}{|c|}{ Recreational zone } \\
\hline \multirow{3}{*}{1} & $0-5$ & Ah & 2.2 & 5.04 & 28 & 5.8 & 0.006 \\
\hline & $5-17$ & $\mathrm{Bt}$ & 1.8 & 1.44 & 18 & 6.9 & $<0.005$ \\
\hline & $0-3$ & Ah & 5.9 & 17.7 & 61 & 13.1 & $<0.005$ \\
\hline \multirow{3}{*}{2} & $3-4$ & $\mathrm{E}$ & 4.8 & 16.6 & 57 & 11.7 & $<0.005$ \\
\hline & $4-14$ & $\mathrm{Bt}$ & 3.9 & 6.76 & 39 & 11.6 & $<0.005$ \\
\hline & 14-17 & $\mathrm{Bg}$ & 4.2 & 3.54 & 33 & 12.6 & $<0.005$ \\
\hline \multirow{2}{*}{3} & $0-4$ & $\mathrm{Ah}$ & 2.2 & 3.02 & 23 & 2.8 & $<0.005$ \\
\hline & $4-30$ & $\mathrm{Bt}$ & 0.4 & 0.84 & 7 & 2.5 & $<0.005$ \\
\hline \multirow[b]{2}{*}{4} & $0-23$ & $\mathrm{Ah}$ & 4.5 & 4.79 & 41 & 7.6 & 0.064 \\
\hline & $23-67$ & $\mathrm{Bt}$ & 7.7 & 3.72 & 33 & 7.3 & $<0.005$ \\
\hline \multicolumn{8}{|c|}{ Residential zone } \\
\hline \multirow{2}{*}{5} & $0-8$ & Ah & 11.3 & 7.34 & 46 & 10.5 & $<0.005$ \\
\hline & $8-15$ & $\mathrm{Bt}$ & 0.2 & 0.08 & 5 & 1.7 & $<0.005$ \\
\hline \multirow[b]{2}{*}{6} & $0-8$ & $\mathrm{Ah}$ & 3.2 & 1.93 & 23 & 9.3 & $<0.005$ \\
\hline & $8-26$ & $\mathrm{Bt}$ & 1.1 & 0.29 & 11 & 5.6 & $<0.005$ \\
\hline \multicolumn{8}{|c|}{ Industrial zone } \\
\hline \multirow{2}{*}{7} & $0-7$ & $\mathrm{Ah}$ & 2.9 & 2.45 & 23 & 6.2 & $<0.005$ \\
\hline & $29-56$ & $\mathrm{Bt}$ & 1.7 & $<0.01$ & 3 & 3.2 & $<0.005$ \\
\hline \multirow[b]{2}{*}{8} & $0-10$ & $\mathrm{Ah}$ & 1.4 & 1.81 & 22 & 4.5 & $<0.005$ \\
\hline & $30-73$ & $\mathrm{Bg}$ & 0.3 & $<0.01$ & 3 & 0.5 & $<0.005$ \\
\hline \multirow[b]{2}{*}{9} & $10-24$ & $\mathrm{Bt}_{1}$ & 4.2 & 2.05 & 18 & 8.9 & $<0.005$ \\
\hline & $50-74$ & $\mathrm{Bt}_{2}$ & 1.9 & 0.26 & 7 & 7.1 & $<0.005$ \\
\hline \multirow{2}{*}{10} & $0-10$ & $\mathrm{C}$ & 17.7 & 15.21 & 79 & 17.8 & 0.144 \\
\hline & $10-20$ & $\mathrm{Cg}$ & 9.7 & 10.21 & 45 & 7.5 & $<0.005$ \\
\hline \multicolumn{8}{|c|}{ Fallow field } \\
\hline \multirow{2}{*}{11} & $0-20$ & $\mathrm{Ah}$ & 5.5 & 4.1 & 28 & 12.4 & $<0.005$ \\
\hline & $20-50$ & $\mathrm{Bh}$ & 7.8 & 4.6 & 32 & 15.3 & $<0.005$ \\
\hline \multirow[t]{2}{*}{12} & $0-20$ & $\mathrm{Ah}$ & 3.1 & 2.93 & 16 & 6.4 & $<0.005$ \\
\hline & MPC & & 33 & 32 & 55 & 20 & 0.5 \\
\hline \multicolumn{3}{|c|}{ Abandoned soils of Yakutsk [37] } & 3.9 & 5.89 & 7 & 2.5 & - \\
\hline \multicolumn{3}{|c|}{ Arable soils of Yakutsk [37] } & 4.4 & 3.60 & 4 & 2.8 & - \\
\hline \multicolumn{3}{|c|}{ Min } & 0.2 & 0.01 & 3 & 0.5 & $<0.005$ \\
\hline \multicolumn{3}{|c|}{ Max } & 17.7 & 17.7 & 79 & 17.8 & 0.144 \\
\hline \multicolumn{3}{|c|}{ Mean } & 4.4 & 4.66 & 28 & 7.9 & - \\
\hline \multicolumn{3}{|c|}{ SD } & 4.1 & 5.12 & 19 & 4.3 & - \\
\hline & $\mathrm{CV}$ & & 91.5 & 109.7 & 68 & 55 & - \\
\hline
\end{tabular}




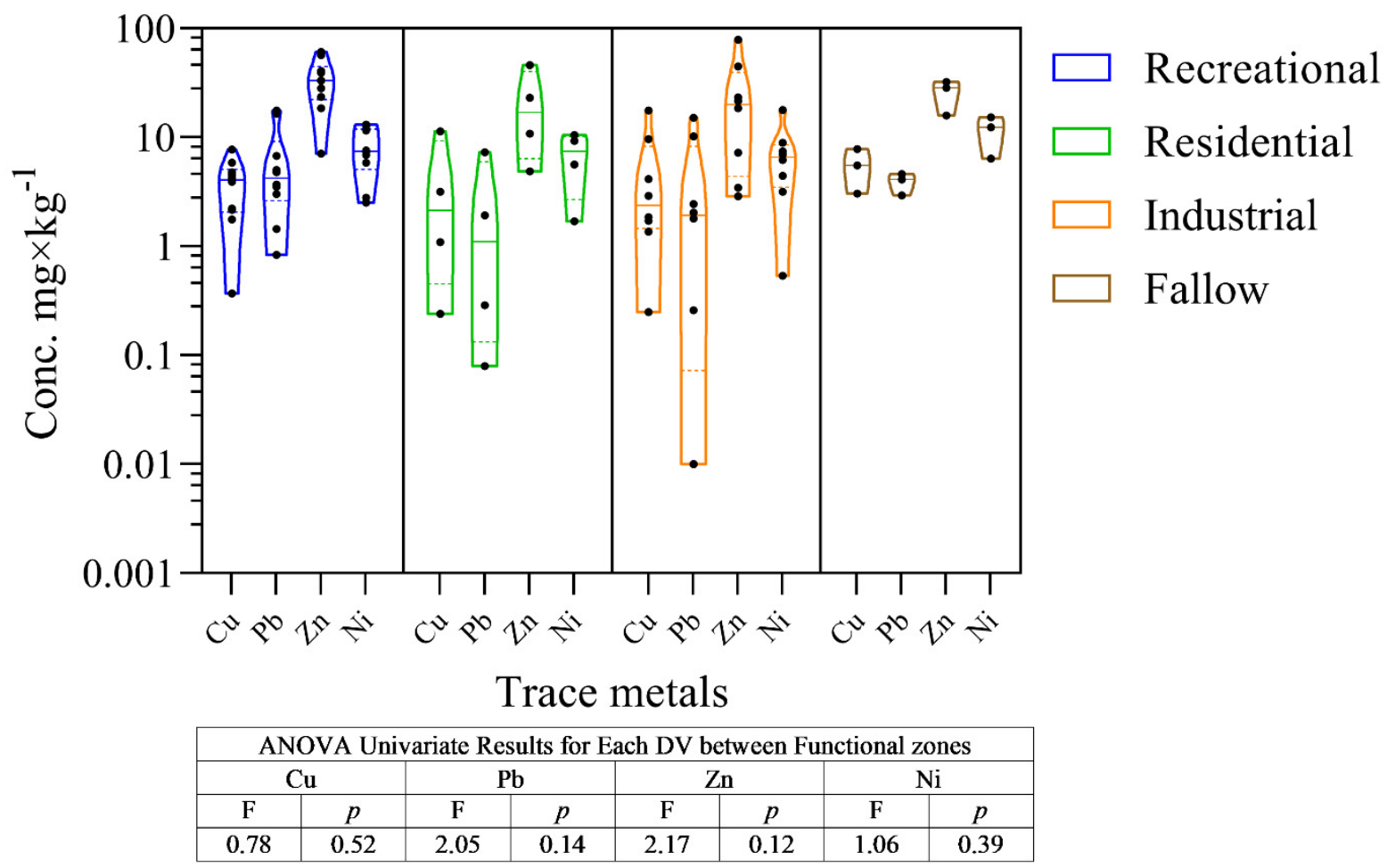

Figure 4. Variation in the content of trace metals and the results of statistical data processing.

No statistically significant differences in the mean values of trace metal concentrations at the $p=0.05$ significance level were found (Figure 4). However, even these $p$-values are considerably higher than the critical significance level of 0.05 , which does not allow us to recognize the significance in the differences in the mean values of metal concentrations in the studied urban functional zones. It is worth noting that the minimum $p$-values, according to the results of the analysis of variance, were obtained for $\mathrm{Pb}$ and $\mathrm{Zn}$.

Alluvial soils, and urban soils as a whole, are the most vulnerable areas of the urban environment [3,4]. Soils are capable of accumulating a significant amount of various pollutants, such as PAHs, trace elements, and pathogenic microflora [39]. In areas not affected by permafrost, these elements are able to migrate into the underlying soil horizons and groundwater, thus being carried out of the urban environment and participating in indirect pollution of adjacent territories [16]. Under the influence of permafrost processes in the soil, priority toxicants are not removed from the soil, but buried at the permafrost table $[7,15]$. Under the influence of the cryogenic factor of soil formation, under the influence of cryoturbations, pollutants are able to migrate from the lower horizons to the upper ones and vice versa $[16,17]$. Under the conditions of climate change, indirect damage to the adjacent territories of the city is possible during the degradation of permafrost and the entrance of toxic substances into groundwater and the Lena River [7].

\subsection{Soil Pollution State}

To qualitatively assess the level of contamination of the studied soils with trace metals, the values of several individual and complex indices were calculated. When calculating the PI index as background concentrations of metals were used concentrations from the recreational zone of the vicinity of Yakutsk (Soil ID-3). Background trace metals concentrations are equal: $\mathrm{Cu}-2.6 ; \mathrm{Pb}-3.02 ; \mathrm{Zn}-23.5 ; \mathrm{Ni}-2.81$.

As can be seen from Table 6, PI index values are highly differentiated between metals and functional zones. The highest values were obtained for the industrial zone, here the level of soil contamination $\mathrm{Cu}, \mathrm{Pb}$ and $\mathrm{Ni}$ is assessed as very strong, $\mathrm{Zn}$ contamination is 
assessed as strong. It is also worth noting the very strong level of $\mathrm{Pb}$ and $\mathrm{Ni}$ pollution in the recreational zone and $\mathrm{Cu}$ pollution in the residential zone.

Table 6. Qualitative assessment of contamination in topsoil horizons. The soil ID corresponds to Table 1.

\begin{tabular}{|c|c|c|c|c|c|c|c|c|}
\hline \multirow[b]{2}{*}{ Soil ID } & \multicolumn{4}{|c|}{ PI } & \multicolumn{2}{|c|}{ PLI } & \multicolumn{2}{|r|}{ RI } \\
\hline & $\mathrm{Cu}$ & $\mathrm{Pb}$ & Zn & $\mathrm{Ni}$ & Value & $\begin{array}{l}\text { Pollution } \\
\text { Status }\end{array}$ & Value & $\begin{array}{c}\text { Potential } \\
\text { Ecological Risk }\end{array}$ \\
\hline \multicolumn{9}{|c|}{ Recreational zone } \\
\hline 1 & 1 & 2 & 1 & 2 & 1 & BL & 26 & Low \\
\hline 2 & 3 & 6 & 3 & 5 & 48 & DSQ & 71 & Low \\
\hline 4 & 2 & 2 & 2 & 3 & 4 & DSQ & 35 & Low \\
\hline \multicolumn{9}{|c|}{ Residential zone } \\
\hline 5 & 5 & 2 & 2 & 4 & 23 & DSQ & 61 & Low \\
\hline 6 & 1 & 1 & 1 & 3 & 1 & $\mathrm{BL}$ & 29 & Low \\
\hline \multicolumn{9}{|c|}{ Industrial zone } \\
\hline 7 & 1 & 1 & 1 & 2 & 1 & $\mathrm{BL}$ & 24 & Low \\
\hline 8 & 1 & 1 & 1 & 2 & 0 & $\mathrm{DP}$ & 16 & Low \\
\hline 9 & 8 & 5 & 3 & 6 & 219 & DSQ & 105 & Moderate \\
\hline \multicolumn{9}{|c|}{ Fallow zone } \\
\hline 10 & 3 & 1 & 1 & 4 & 5 & DSQ & 44 & Low \\
\hline 11 & 1 & 1 & 1 & 2 & 1 & $\mathrm{BL}$ & 25 & Low \\
\hline
\end{tabular}

DP—denote perfection, BL—only baseline levels of pollution, DSQ—-deterioration of soil quality.

The complex assessment of soil quality in terms of total metal contamination revealed that study soils are subjected to significant anthropogenic load. The results of the calculation of the PLI index show that almost half of the investigated soils are in the process of deterioration of soil quality. Although soils are in the process of deteriorating their quality, the level of potential environmental risk (RI) is at a low level for all of the studied soils, except for one sample in the industrial zone, here the level of environmental risk is assessed as moderate.

The passing of "Strategy for the socio-economic development of the Republic of Sakha (Yakutia) for the period up to 2030 with the definition of a target vision until 2050" [28] provides for the large-scale development of the industry of the Republic of Sakha (Yakutia). Therefore, it can be assumed that in the next decade there will be a significant increase in the anthropogenic load on the permafrost ecosystems of the North [34]. The construction and operation of the Eastern Siberia-Pacific Ocean (ESPO) pipeline system is inevitably associated transformation of natural ecosystems of southern Yakutia [56]. The construction of this system will take place along the drainage basin of the Lena River and other large rivers, thus anthropogenic impact can spread along rivers, channels and cities [34]. The most vulnerable functional zone is the alluvial territories of the city, due to the low biological activity and stability, an active accumulation of priority toxicants of anthropogenic origin can occur here $[3,7,35]$. Today, alluvial areas are used as a city beach, as well as a residential zone, which could potentially affect the health of the local population. A distinctive feature of soils developing in the permafrost zone is their low sorption capacity [16]. In soils, there is an accumulation of priority toxicants, polyromantic hydrocarbons, as well as oil products, which, due to their low biological activity, can persist here for a long time $[4,7,16]$.

Previously carried out works focused on the study of agricultural areas of the city [23], quarry complexes of the region [57] and pathogenic soil microflora [38]. In our work, we managed to analyze the pollution of the city's soils, determine their agrochemical characteristics and identify potential risks for public health. The limitations of this work are the lack of knowledge in the development of urban soils in permafrost conditions. The obtained data can provide information on current events, while in non-permafrost areas, it is possible to predict the development of the soil cover [1,2,4,39]. Therefore, the results obtained can make a significant contribution to the development of science in this direction. 


\section{Conclusions}

As a result of the work, the soils of various functional zones of the polar greatest city (residential, recreational, industrial and fallow lands) were studied. Were identified 4 types of soil developing in these areas. The zonal type of soil is Podzols in recreational and industrial zones. Fluvisols are developing in the alluvial areas (residential). Umbrisols are formed on the fallow lands of the city. According to the agrochemical analysis, a relatively low content of nitrogenous compounds (up to $28 \mathrm{mg} \times \mathrm{kg}^{-1} \mathrm{~N}^{-\mathrm{NH}_{4}}$ and up to $2 \mathrm{mg} \times \mathrm{kg}^{-1} \mathrm{NO}_{3}$ ) is noted in soils, up to $410 \mathrm{mg} \times \mathrm{kg}^{-1} \mathrm{P}_{2} \mathrm{O}_{5}$ accumulates in the soils of the recreational zone and up to $372 \mathrm{mg} \times \mathrm{kg}^{-1} \mathrm{~K}_{2} \mathrm{O}$ in fallow lands. Based on the data obtained from the analysis of the territory pollution with trace elements, it was revealed that the MPC level for $\mathrm{Zn}\left(79 \mathrm{mg} \times \mathrm{kg}^{-1}\right)$ was exceeded in the quarry complex of the city. For other studied elements $(\mathrm{Cu}, \mathrm{Pb}, \mathrm{Ni}$ and $\mathrm{Cd})$, no excess was found. As a result of calculating pollution indexes (PI, PLI, RI), it was noted that the greatest threat is presented by the territory of the quarry complex. With an increase of anthropogenic impact on the urban environment, industrial and alluvial zones may become the most vulnerable areas of the city, due to the low recalcitrance resistance of these soils to external factors.

Author Contributions: V.P. performed the expedition with fieldwork and soil sampling; V.P., T.N. and E.A. paper writing laboratory analyses, E.M.-field research, conceptualization. All authors have read and agreed to the published version of the manuscript.

Funding: This work was supported by the Ministry of Science and Higher Education of the Russian Federation in accordance with agreement № 075-15-2020-922 date 16.11.2020 on providing a grant in the form of subsidies from the Federal budget of Russian Federation. The grant was provided for state support for the creation and development of a World-class Scientific Center "Agrotechnologies for the Future".

Institutional Review Board Statement: Not applicable.

Informed Consent Statement: Not applicable.

Data Availability Statement: The data that support the findings of this study are available from the corresponding author, upon reasonable request.

Conflicts of Interest: The authors declare no conflict of interest.

\section{References}

1. Morel, J.L.; Schwartz, C.; Florentin, L.; de Kimpe, C. Urban Soils. In Encyclopedia of Soils in the Environment; Hillel, D., Ed.; Elsevier: Oxford, UK, 2005; pp. 202-208. Available online: http:/ /1.droppdf.com/files/3eUvv/encyclopedia-of-soils-in-the-environmentvolume-3.pdf (accessed on 21 May 2021).

2. Bullock, P. Soils in the Urban Environment; Gregory, P.J., Ed.; Wiley-Blackwell: Berlin, Germany, 1991; p. 184.

3. Dymov, A.A.; Kaverin, D.A.; Gabov, D.N. Properties of soils and soil-like bodies in the Vorkuta area. Eurasian Soil Sci. 2013, 46, 217-224. [CrossRef]

4. Agapkina, G.I.; Chikov, P.A.; Shelepchikov, A.A.; Brodskii, E.S.; Feshin, D.B.; Bukhan'Ko, N.G.; Balashova, S.P. Polycyclic aromatic hydrocarbons in soils of Moscow. Mosc. Univ. Soil Sci. Bull. 2007, 62, 149-158. [CrossRef]

5. Appelo, C.A.J.; Postma, D. Geochemistry, Groundwater and Pollution, 2nd ed.; CRC Press: London, UK, $2005 ;$ p. 635.

6. Lehmann, A. Technosols and other proposals on urban soils for the WRB (World Reference Base for Soil Resources). Int. Agrophys. 2006, 20, 129-134.

7. Ji, X.; Abakumov, E.; Antcibor, I.; Tomashunas, V.; Knoblauch, C.; Zubzycki, S.; Pfeiffer, E.-M. Influence of Anthropogenic Activities on Metals in Arctic Permafrost: A Characterization of Benchmark Soils on the Yamal and Gydan Peninsulas in Russia. Arch. Environ. Contam. Toxicol. 2019, 76, 540-553. [CrossRef] [PubMed]

8. Balbus, J.M.; Boxall, A.B.A.; Fenske, R.A.; McKone, T.E.; Zeise, L. Implications of global climate change for the assessment and management of human health risks of chemicals in the natural environment. Environ. Toxicol. Chem. 2013, 32, 62-78. [CrossRef] [PubMed]

9. Jaffe, D.; Cerundolo, B.; Rickers, J.; Stolzberg, R.; Baklanov, A. Deposition of sulfate and heavy metals on the Kola Peninsula. Sci. Total. Environ. 1995, 160-161, 127-134. [CrossRef]

10. Dobrovolsky, G.V. Soils of the Floodplains of the Center of the Russian Plain; Izdvo MGU: Moscow, Russia, 2005 ; p. 293. 
11. Boike, J.; Nitzbon, J.; Anders, K.; Grigoriev, M.; Bolshiyanov, D.; Langer, M.; Lange, S.; Bornemann, N.; Morgenstern, A.; Schreiber, P.; et al. A 16-year record (2002-2017) of permafrost, active-layer, and meteorological conditions at the Samoylov Island Arctic permafrost research site, Lena River delta, northern Siberia: An opportunity to validate remote-sensing data and land surface, snow, and permafrost models. Earth Syst. Sci. Data 2019, 11, 261-299. [CrossRef]

12. Kutzbach, L.; Wagner, D.; Pfeiffer, E.-M. Effect of microrelief and vegetation on methane emission from wet polygonal tundra, Lena Delta, Northern Siberia. Biogeochemistry 2004, 69, 341-362. [CrossRef]

13. Lara, R.J.; Rachold, V.; Kattner, G.; Hubberten, H.W.; Guggenberger, G.; Skoog, A.; Thomas, D.N. Dissolved organic matter and nutrients in the Lena River, Siberian Arctic: Characteristics and distribution. Mar. Chem. 1998, 59, 301-309. [CrossRef]

14. Jones, A.; Stolbovoy, V.; Tarnocai, C.; Broll, G.; Spaargaren, O.; Montanarella, L. Soil Atlas of the Northern Circumpolar Region, European Commission; Publications Office of the European Union: Luxembourg, 2010; p. 144.

15. Ji, X.; Abakumov, E.; Polyako, V.; Xie, X.; Dongyang, W. The ecological impact of mineral exploitation in the Russian Arctic: A field-scale study of polycyclic aromatic hydrocarbons (PAHs) in permafrost-affected soils and lichens of the Yamal-Nenets autonomous region. Environ. Pollut. 2019, 255, 113239. [CrossRef]

16. Ji, X.; Abakumov, E.; Tomashunas, V.; Polyakov, V.; Kouzov, S. Geochemical pollution of trace metals in permafrost-affected soil in the Russian Arctic marginal environment. Environ. Geochem. Health 2020, 42, 4407-4429. [CrossRef] [PubMed]

17. Abakumov, E.; Shamilishviliy, G.; Yurtaev, A. Soil polychemical contamination on Beliy Island as key background and reference plot for Yamal region. Pol. Polar Res. 2017, 38, 313-332. [CrossRef]

18. Antcibor, I.; Eschenbach, A.; Zubrzycki, S.; Kutzbach, L.; Bolshiyanov, D.; Pfeiffer, E.-M. Trace metal distribution in pristine permafrost-affected soils of the Lena River delta and its hinterland, northern Siberia, Russia. Biogeosciences 2014, 11, 1-15. [CrossRef]

19. Halbach, K.; Mikkelsen, Ø.; Berg, T.; Steinnes, E. The presence of mercury and other trace metals in surface soils in the Norwegian Arctic. Chemosphere 2017, 188, 567-574. [CrossRef] [PubMed]

20. Knoblauch, C.; Beer, C.; Sosnin, A.; Wagner, D.; Pfeiffer, E.-M. Predicting long-term carbon mineralization and trace gas production from thawing permafrost of Northeast Siberia. Glob. Chang. Biol. 2013, 19, 1160-1172. [CrossRef]

21. Zubrzycki, S.; Kutzbach, L.; Pfeiffer, E.-M. Permafrost-affected soils and their carbon pools with a focus on the Russian Arctic. Solid Earth 2014, 5, 595-609. [CrossRef]

22. Rogov, V.; Konistsev, V. The influence of cryogenesis on clay materials. Cryospere Earth 2008, 12, 51-59.

23. Desyatkin, R.V.; Desyatkin, A.R.; Fedorov, P.P. Temperature regime of the forest soils, Central Yakutia. Earth's Cryosphere 2012, 16, 70-78.

24. Gubin, S.V.; Lupachev, A.V. Soils of loamy watersheds of coastal tundra in the north of Yakutia: Pedogenetic conditions and processes. Eurasian Soil Sci. 2017, 50, 133-141. [CrossRef]

25. Gubin, S.V. The Holocene history of soil development in coastal lowlands of northern Yakutia. Eurasian Soil Sci. 2001, 34, 1257-1264.

26. Liverovsky, Y.A. Soils of the Far North and some questions of their genesis and classification. Eurasian Soil Sci. 1983, 5, 5-15.

27. Boike, J.; Kattenstroth, B.; Abramova, K.; Bornemann, N.; Chetverova, A.; Fedorova, I.; Fröb, K.; Grigoriev, M.; Grüber, M.; Kutzbach, L.; et al. Baseline characteristics of climate, permafrost and land cover from a new permafrost observatory in the Lena River Delta, Siberia (1998-2011). Biogeosciences 2013, 10, 2105-2128. [CrossRef]

28. President of Russian Federation. On the Strategy for the Development of the Arctic Zone of the Russian Federation and Ensuring National Security for the Period up to 2035. Moscow, Russia, 2020; p. 42. Available online: http:/ / en.kremlin.ru/acts/news/64274 (accessed on 25 May 2021).

29. Romanovsky, V.E.; Drozdov, D.S.; Oberman, N.G.; Malkova, G.V.; Kholodov, A.L.; Marchenko, S.S.; Moskalenko, N.G.; Sergeev, D.O.; Ukraintseva, N.G.; Abramov, A.A.; et al. Thermal state of permafrost in Russia. Permafr. Periglac. Process. 2010, 21, 136-155. [CrossRef]

30. Rovinsky, F.; Pastukhov, B.; Bouyvolov, Y.; Burtseva, L. Present day state of background pollution of the natural environment in the Russian Arctic in the region of the Ust-Lena Reserve. Sci. Total. Environ. 1995, 160-161, 193-199. [CrossRef]

31. Vodyanitsky, Y.N. Diagnostics of Waterlogged Mineral Soils; Soil Science institute of V.V. Dockuhaev: Moscow, Russia, $2008 ;$ p. 82.

32. Bolshiyanov, D.Y.; Makarov, A.S.; Schneider, V.; Stoof, G. Origin and Development of the Delta Lena River; AARI: St. Petersburg, Russia, 2013; p. 268.

33. Abakumov, E.; Morgun, E.; Pechkin, A.; Polyakov, V. Abandoned agricultural soils from the central part of the Yamal region of Russia: Morphology, diversity, and chemical properties. Open Agric. 2020, 5, 94-106. [CrossRef]

34. Okonesnikova, M.V. Influence of the main gas pipeline construction on the soil cover in the conditions of central Yakutia. Bull. KrasGAU 2012, 9, 50-53.

35. Okonesnikova, M.V. Current state and prediction of changes in soils of the middle Lena valley (Central Yakutia). Tomsk. State Univ. J. Biol. 2013, 3, 7-18.

36. Okonesnikova, M.V.; Ivanova, A.Z. Soils and technogenic surface formations of an industrial base of Yakutsk city. Vestn. North-East. Fed. Univ. 2020, 6, 5-19.

37. Savvinov, D.D.; Makarova, M.P.; Timofeev, A.G.; Kowalski, D.V. Trace elements in the soils of the suburban zone of Yakutsk. Nauka Obraz. 2014, 2, 7-10. 
38. Yadrikhinskaya, V.K.; Shchelchkova, M.V. Microbiological characteristics of permafrost meadow-black earth soils of the city of Yakutsk in the area of influence of emissions of motor transport. Mod. Trends Dev. Sci. Technol. 2015, 7, 53-55.

39. Lodygin, E.D.; Chukov, S.N.; Beznosikov, V.A.; Gabov, D.N. Polycyclic aromatic hydrocarbons in soils of Vasilievsky Island (St. Petersburg). Eurasian Soil Sci. 2008, 41, 1321-1326. [CrossRef]

40. WRB, F. IUSS Working Group WRB World Reference Base for Soil Resources 2014, Update 2015. 2015, p. 195. Available online: http:/ / www.fao.org/3/i3794en/I3794en.pdf (accessed on 15 May 2021).

41. Jahn, R.; Blume, H.P.; Spaargaren, O.; Schad, P. Guidelines for Soil Description; Food and Agriculture Organization of the United nations: Rome, Italy, 2006.

42. Walkley, A. A Critical Examination of a Rapid Method for Determining Organic Carbon in Soils—Effect of Variations in Digestion Conditions and of Inorganic Soil Constituents. Soil Sci. 1947, 63, 251-264. [CrossRef]

43. Bowman, G.; Hutka, J. Particle Size Analysis. In Soil Physical Measurment and Interpritation for Land Evaluation; McKezie, N., Coughlan, K., Cresswell, H., Eds.; CSIRO Publishing: Clayton North, VIC, Australia, 2002; pp. 224-239.

44. Soils. Determination of Mobile Phosphorus and potassium Compounds by Kirsanov Method Modified by CINAO. 2013. Available online: http:/ / docs.cntd.ru/document/1200094361 (accessed on 19 May 2021). (In Russian)

45. ISO/TS 14256-1-2003. Soil Quality-Determination of Nitrate, Nitrite and Ammonium in Field Moist Soils by Extraction with Potassium Chloride Solution-Part 1: Manual Method (ISO/TS 14256-1-2003:2003). 2003, p. 14. Available online: https: //www.sis.se/api/document/preview/903656/ (accessed on 15 April 2021).

46. ISO 11047-1998. Soil Quality-Determination of Cadmium, Cobalt, Copper, Lead, Manganese, Nickel and Zinc in Aqua Regia Extracts of Soil-Flame and Electrothermal Atomic Absorption Spectrometric Methods. 1998, p. 18. Available online: https:/ / www.sis.se/api/document/preview/615727/ (accessed on 10 April 2021).

47. Kowalska, J.B.; Mazurek, R.; Gąsiorek, M.; Zaleski, T. Pollution indices as useful tools for the comprehensive evaluation of the degree of soil contamination-A review. Environ. Geochem. Health 2018, 40, 2395-2420. [CrossRef]

48. Hakanson, L. An ecological risk index for aquatic pollution control.a sedimentological approach. Water Res. 1980, 14, 975-1001. [CrossRef]

49. Orlov, D.S. Soil Chemistry: A Textbook; Moscow State University: Moscow, Russia, 1985.

50. Abakumov, E.V.; Polyakov, V.; Orlova, K.S. Podzol development on different aged coastal bars of Lake Ladoga. Tomsk. State Univ. J. Biol. 2019, 48, 6-31. [CrossRef] [PubMed]

51. Strawn, D.G.; Bohn, H.L.; O'Connor, G.A. Soil Chemistry, 5th ed.; Wiley-Blackwell: Oxford, UK, 2019 ; p. 376.

52. Yao, S.-H.; Zhang, Y.-L.; Han, Y.; Han, X.-Z.; Mao, J.-D.; Zhang, B. Labile and recalcitrant components of organic matter of a Mollisol changed with land use and plant litter management: An advanced 13C NMR study. Sci. Total. Environ. 2019, 660, 1-10. [CrossRef]

53. Abakumov, E. Saint Petersburg State University Content of available forms of nitrogen, potassium and phosphorus in ornithogenic and other soils of the Fildes Peninsula (King George Island, Western Antarctica). Biol. Commun. 2008, 63, 109-116. [CrossRef]

54. Knicker, H. How does fire affect the nature and stability of soil organic nitrogen and carbon? A review. Biogeochemistry 2007, 85, 91-118. [CrossRef]

55. Sahoo, P.K.; Equeenuddin, S.M.; Powell, M.A. Trace Elements in Soils around Coal Mines: Current Scenario, Impact and Available Techniques for Management. Curr. Pollut. Rep. 2016, 2, 1-14. [CrossRef]

56. Gavrilyeva, T.N.; Stepanova, N.A. ESPO and power of Siberia: The impact of mega-projects on the economy and environment of Yakutia. Reg. Econ. Sociol. 2016, 4, 237-248.

57. Gololobova, A.G.; Legostaeva, Y.B. Ecogeochemical monitoring of soil cover on diamond mining site in Western Yakutia. Bull. Tomsk. Polytech. Univ. 2020, 331, 146-157. 